\title{
Resistencia social en el libroarte de México del siglo XXI: relatos de la otredad"
}

\author{
María Graciela Patrón Carrillo
}

\begin{abstract}
Recibido: 8 de agosto de 2018
Evaluado: 3 de septiembre de 2018

Aceptado: 23 de octubre de 2018
\end{abstract}

Citar como: Patrón Carrillo, M. G. (2019). Resistencia social en el libroarte de México del siglo XXI: relatos de la otredad. Hallazgos, 16(31), 121-145. Doi: https://doi.org/10.15332/s1794-38 41.2019.0031.05

\section{Resumen}

Este artículo aborda el libroarte en México en el siglo XXI como un espacio de resistencia, en el que se llevan a cabo prácticas que confrontan los mecanismos de poder. Tales prácticas se manifiestan en dos estadios, relacionados con las temáticas abordadas por los artistas: la producción de obras que tratan asuntos de denuncia y crítica social y las que exploran el tema de la memoria colectiva. Para sustentar lo anterior, se retoman los postulados de dos autores principales: en primera instancia, el trabajo de Michel Foucault, sus reflexiones en torno a las sociedades de control y cómo sus métodos de dominación detonan ciertas respuestas - dentro del propio sistema - para contrarrestarlos; por otro lado, las reflexiones de Anna Maria Guasch acerca del arte como archivo, una preocupación de los artistas por crear piezas en las que se almacena información, a través de las cuales se detonan nuevas miradas sobre la historia. Finalmente, se hablará de dos casos en los que el libroarte funciona como medio de denuncia, crítica social y memoria colectiva: lo sucedido a los 43 estudiantes de Ayotzinapa y la herencia maya, a partir de los cuales surgen obras expuestas en ferias alrededor del mundo e integradas a colecciones de universidades en diversos países. Sus relatos permiten conocer personajes y eventos del México del siglo XXI desde miradas diferentes de las versiones oficiales, los protegen de la desaparición y de esta manera se integran a los discursos de resistencia.

Palabras clave: México, libroarte, resistencia, denuncia, memoria colectiva.

Artículo de reflexión. Se desprende del trabajo de tesis doctoral titulado El libroarte en México en el siglo XXI como dispositivo de resistencia social, que actualmente se lleva a cabo en el Doctorado Interinstitutional en Arte y Cultura de la Universidad Michoacana de San Nicolás de Hidalgo, Programa Nacional de Posgrados de Calidad, Consejo Nacional de Ciencia y Tecnología.

* Universidad Michoacana de San Nicolás de Hidalgo, México. Correo electrónico: grachpatron@gmail.com ORCID: https://0rcid.org/0000-00 03-2044-2351 


\section{Social resistance in book arts of Mexico of the 21st century: Accounts of otherness}

\begin{abstract}
This article approaches the book art in Mexico in the 21st century as a space of resistance, in which practices that confront power mechanisms are carried out. Such practices are displayed in two stages, related to the themes addressed by the artists: the production of works that deal with issues of denunciation and social criticism and those that explore the theme of collective memory. To support the above, the postulates of two main authors are taken up again: in the first instance, the work of Michel Foucault, his reflections on the societies of control and how their methods of domination detonate certain answers - within the system itself - to counteract them; on the other hand, the reflections of Anna Maria Guasch about art as a file, a concern of artists to create pieces in which information is stored, through which new perspectives on history are detonated. Finally, we will discuss about two cases in which the book art works as a means of denunciation, social criticism and collective memory: what happened to the 43 students of Ayotzinapa and the Mayan heritage, from which works are exposed at fairs around the world and integrated to university collections in different countries. Their stories allow to know characters and events of the 21st century Mexico from views different from the official versions, they protect them from disappearing and in this way they are integrated to the discourses of resistance.
\end{abstract}

Keywords: Mexico, book arts, resistance, denunciation, collective memory.
Received: August 8, 2018

Evaluated: September 3, 2018

Accepted: October 23, 2018 


\section{Resistência social no livro de artista do México no século XXI: relatos da alteridade}

Recebido: 8 de agosto 2018 Avaliado: 3 de setembro de 2018 Aceito: 23 de outubro de 2018

\section{Resumo}

Este artigo aborda o livro de artista no México no século XXI como um espaço de resistência no qual se realizam práticas que confrontam os mecanismos de poder. Tais práticas manifestam-se em dois estádios, relacionados com as temáticas abordadas pelos artistas: a produção de obras que tratam assuntos de denuncia e crítica social e as que exploram o tema da memória coletiva. Para sustentar o anterior, retomam-se os postulados dos autores principais: em primeiro lugar o trabalho do Michel Foucault, suas reflexões sobre as sociedades do controle e como seus métodos de dominação detonam determinadas respostas - dentro do próprio sistema - para os contra-arrestar; de outro lado, as reflexões da Anna Maria Guasch acerca da arte como arquivo, uma preocupação dos artistas por criar peças nas que se guarda informação, através das quais se produzem novos olhares sobre a história. Finalmente se abordaram dois casos nos quais o livro de artista funciona como meio de denúncia, crítica social e memória coletiva: o sucedido aos 43 estudantes de Ayotzinapa e a herança maia, a partir dos quais surgem obras expostas em feiras ao redor do mundo e integradas nas coleções de universidades em diversos países. Seus relatos permitem conhecer personagens e eventos do México no século XXI desde olhares diferentes das versões oficiais, os protegem da desaparição e desta maneira integram-se aos discursos de resistência.

Palavras-chave: México, livro de artista, resistência, denuncia, memória coletiva. 


\section{INTRODUCCIÓN}

A lo largo de las siguientes páginas, se desarrolla una reflexión acerca del libroarte de México en el siglo XXI, cuando se le acomete como un espacio de resistencia. Esto implica que los artistas utilizan este género plástico con la intención de confrontar los discursos de los mecanismos de poder, lo cual sucede en dos estadios relacionados con las temáticas que abordan sus creadores: obras que tratan asuntos de denuncia y crítica social y obras en las que se explora la memoria colectiva. Aquellas de denuncia y crítica social señalan los aspectos en que falla el mecanismo de control, es decir, exhiben las fisuras en la estructura de poder; por otro lado, las que abordan la memoria colectiva funcionan como testimonio de un acontecer, al cual pueden acceder lectores en distintos entornos.

En ambos casos, las obras desembocan en relatos de la otredad, aunque con funciones distintas; mientras la denuncia y crítica social cuestionan el funcionamiento de la estructura de poder, haciendo tambalear su estabilidad, la memoria se enfoca en la preservación de acontecimientos y modos de vida que corren el riesgo de desaparecer. De esta manera, se confrontan las versiones oficiales en torno a distintos sucesos, se construyen testimonios de eventos y modos de interacción con el mundo y se forman nuevas miradas en torno a la realidad del país.

Para sustentar lo anterior, se inicia con una breve explicación del libroarte, sus orígenes en la década de los sesenta, el surgimiento del término, así como su traducción al español; posteriormente, su llegada y desarrollo en México. Una vez sentadas estas bases, se retoman los postulados de dos autores principales: por un lado, el trabajo de Michel Foucault sobre las sociedades de control y cómo sus métodos de dominación detonan ciertas respuestas, dentro del propio sistema, que sirven para contrarrestarlos; a ello se suman las reflexiones de Anna Maria Guasch acerca de la capacidad del arte de fungir como archivo, en el que la autora señala la preocupación de los artistas, presente desde mediados del siglo pasado, por crear piezas en las que se almacena información que detona nuevas miradas sobre la historia.

Finalmente, se tocarán dos casos en los que el libroarte de México funciona como resistencia, obras expuestas en distintas ferias alrededor del mundo que se han integrado a colecciones privadas, así como a bibliotecas de universidades en diversos países. A través de sus relatos, les es posible a varios públicos conocer la historia de personajes y eventos que definen al México del siglo XXI, cuyos testimonios muestran una aproximación de los hechos distinta de la ofrecida por las versiones oficiales que a la vez los protegen del olvido. Primero como medio de denuncia y crítica social - que deviene la exposición de las fallas en la estructura de poder - y posteriormente a través de la memoria, lo cual se traduce en un trabajo de archivo.

Tales casos son la desaparición de los 43 estudiantes normalistas de Ayotzinapa en septiembre de 2014, que deriva en la creación de tres piezas de relevancia internacional y el trabajo del Taller Leñateros en Chiapas que responde al interés por preservar y difundir la herencia y las tradiciones mayas. 


\section{LIBROARTE}

El libroarte es una vertiente de las artes plásticas que retoma la estructura y los elementos tradicionales del libro, tales como portada, empastado, narrativa secuencial, ritmo de lectura y texto, para llevarlos al ámbito de la visualidad. Puede definirse de la siguiente manera: "El libroarte es toda pieza de arte que está basada ya sea en la forma o en el concepto del libro común y que ha sido concebida por un artista, aunque puede haber otras personas involucradas en su elaboración"1.

Si bien siempre ha existido una relación entre el objeto-libro y las artes visuales, al igual que entre la escritura y las imágenes como elementos para producir narrativas, el libroarte en tanto género de la plástica surge en la década de los sesenta, a la par de movimientos tales como Fluxus (que integraba objetos cotidianos al trabajo del arte, entre ellos, el libro), el arte de concepto (que exploraba la relación entre lo matérico y la idea intangible) y el arte tautológico (que experimentaba con el lenguaje y la escritura como elementos de las artes visuales).

El libroarte es considerado como un género híbrido debido a que no se sujeta a una técnica específica, trasciende fronteras entre disciplinas e incluye en una misma pieza diversos procesos y materiales, tales como la estampa en sus múltiples vertientes, la fotografía, el dibujo, la pintura, el bordado, el collage, el texto y objetos varios. En cuanto a su presentación, puede colocarse a modo de

1 La definición forma parte del trabajo de investigación de la autora que actualmente lleva a cabo en el Doctorado Interinstitucional en Arte y Cultura en la Universidad Michoacana de San Nicolás de Hidalgo. instalación, ser empastado o bien guardarse dentro de diferentes clases de contenedores: una caja, un sobre, una bolsa, una botella, entre muchos otros.

El término book-art aparece por primera vez en la década de los ochenta, acuñado por el crítico norteamericano Clive Phillpot en una serie de ensayos publicados en la revista ArtForum en 1982, cuando hablaba sobre una nueva vertiente plástica que tomaba como base la forma del libro tradicional para llevarla hacia otros territorios. Book-art permitía establecer una diferencia entre estas piezas y otros términos similares, tales como el art book (el libro que habla acerca de un artista o una corriente artística) o las book arts (las "artes del libro", técnicas de impresión, reproducción tipográfica, creación de imágenes, encuadernación y empastados). El vocablo encuentra su traducción al español como libroarte cuando la artista e investigadora española Bibiana Crespo realiza en 1999 su tesis doctoral Libroarte: concepto y proceso de una creación contemporánea; desde entonces, es utilizado cada vez con mayor frecuencia tanto por artistas como teóricos por interesados en el tema.

El libroarte llega a México a mediados de la década de los setenta a través de dos figuras centrales: Ulises Carrión y Felipe Ehrenberg, artistas mexicanos quienes durante sus estadías en Europa entraron en contacto con las nuevas tendencias de la plástica, se involucraron en la producción y difusión de estas piezas, además de intercambiar ideas y reflexiones en torno a este género. Aunque Carrión permaneció radicado en Europa el resto de su vida, no perdió el contacto con México, así, el texto "El arte nuevo de hacer libros" se publicó en la revista mexicana 
Plural número 41 y se mantiene como uno de los referentes obligados para creadores e investigadores. Por otro lado, Ehrenberg vuelve a México en 1974 y comienza con la difusión de esta nueva manera de aproximación al objeto-libro, lo cual provoca el interés de los artistas, de modo que durante la década de los ochenta y parte de la década de los noventa surgen y trabajan colectivos y espacios dedicados a la producción, exposición y difusión del libroarte, tales como La Cocina Ediciones y El Archivero.

Sin embargo, es a partir del siglo XXI, y en particular durante los últimos diez años, cuando el libroarte en México ha experimentado un verdadero crecimiento, con la impartición de cursos y talleres en espacios independientes, así como materias que forman parte de los planes de estudio en escuelas de artes. A ello se suman los aportes desde el punto de vista de la investigación y de los foros de discusión que se llevan a cabo en varios puntos de la república, tales como la Universidad Autónoma de Ciudad Juárez, la Universidad Michoacana de San Nicolás de Hidalgo o la Universidad Veracruzana, por mencionar algunos casos; de esta manera, se sigue fomentando el interés de las nuevas generaciones por trabajar con el objeto-libro como una obra de arte.

La producción del libroarte en México en el siglo XXI se encuentra condicionada por una serie de factores y circunstancias, las cuales se manifiestan en las temáticas que trabajan los artistas. Esto sucede debido a que el libroarte es un producto cultural, es decir, forma parte de los objetos elaborados por una sociedad en un periodo histórico determinado. Como tal, refleja los órdenes simbólicos operantes entre los miembros de una comunidad; por ello, es natural que los creadores reflexionen sobre los problemas que afectan a su entorno y así la memoria colectiva, denuncia y crítica social resultan tan pertinentes. A través de ellas es posible señalar los aspectos en que falla la estructura política y social a la vez que recuperar el testimonio de ciertos personajes, modos de vida o eventos que permiten confrontar los relatos oficiales, proponiendo esencialmente otras maneras de mirar y construir la historia nacional.

\section{Michel Foucault: RESISTENCIA}

El trabajo de Michel Foucault se desarrolla en torno al juego de tensiones que tiene lugar entre los mecanismos reguladores de la vida y sus repercusiones dentro del propio sistema, en las reacciones de sus integrantes. Desde su pensamiento, las prácticas del poder se llevan a cabo como estrategias de exclusión a todo lo que sale de la norma, es decir, lo que se diferencia del comportamiento establecido, aceptado y practicado por los miembros de una sociedad. Al respecto, Giraldo menciona que "el poder disciplinario fabrica individuos, encauza sus conductas, los guía en la multitud multiplicando sus fuerzas" (2006, p. 110). Sin embargo, serán los propios discursos de dominación los que impulsan la transformación del mecanismo a través de la respuesta que provocan entre sus componentes.

Acorde con Foucault (1980), tanto el poder como las acciones que lo resisten se extienden a manera de red, entablando relaciones entre elementos. Mientras el primero tiene por objetivo la normalización de la conducta, las segundas generan prácticas fuera de tales ordenamientos, que confrontan los 
mecanismos de control; ello las proyecta como una amenaza para el equilibrio de la estructura y por tal razón deben ser señaladas, sometidas o excluidas. En tales casos, la resistencia no se limita a la lucha por derechos legales o políticos, sino que se trata de la preservación de la vida e historia de todos aquellos grupos o individuos prescindibles al sistema.

Esto a su vez deviene dos fenómenos: la creación de estrategias para mantener el control y la formación de nuevos grupos o personajes al margen del pensamiento hegemónico, los cuales producen sus propios órdenes. Como resultado, la concepción del poder se complejiza, de una fuerza opresora inicial que somete, a un motor que propicia la aparición de prácticas de resistencia. Entre estos modos de vida y prácticas que suponen un contrapeso al sistema de control, se encuentra el quehacer artístico, que produce miradas y subjetividades fuera de la normalización del pensar, el sentir y el vivir. El artista se relaciona con la figura del loco, quien es capaz de mirar distinto llevando a cabo procesos mentales impredecibles; desde el pensamiento de Foucault, el loco es aquel cuyo comportamiento rebasa lo esperado y desafía el orden.

El poeta hace lo mismo: reta los órdenes del lenguaje, construye nuevas relaciones entre elementos; así, la poesía, y por extensión el resto de las manifestaciones artísticas, se entienden como formas de locura en tanto trastocan los modos de significación establecidos. Abordan la realidad desde perspectivas distintas del pensamiento hegemónico, la reformulan y producen nuevas subjetividades; en este proceso, también proponen vías de escape a las formas de sujeción, aquellas cuyo objetivo es el control de la subjetividad. Al respecto, Giraldo menciona que "la resistencia es creativa, es una práctica productiva que rechaza los modos normales de vida" (2008, p. 99). Aquí se encuentra su potencial de resistencia, en la posibilidad de detonar pensamiento y afectividad fuera de los lineamientos permitidos por el mecanismo de control.

Ya que hoy día la humanidad está inmersa en una cultura eminentemente visual que condiciona la manera en que se aprehende la realidad e interactúa con el mundo, se vuelve imperativo comprender el alcance de las imágenes en los procesos de construcción del sujeto, en el imaginario colectivo y su importancia desde el punto de vista del apoyo o rechazo a los mecanismos reguladores del pensamiento. Al respecto, Baudrillard (1969) señala que las imágenes tienen siempre un matiz social y en consecuencia se encuentran ligadas al campo de acción de la política y los sistemas de poder; así, es natural que la estructura dominante haga uso de ellas para sus fines de regulación y ordenamiento como signos que contribuyen a dictar los cánones de vida.

Sin embargo, existen imágenes que se proyectan como su contraparte, pues, si el signo interactúa con otros para crear códigos que rigen la vida, también se puede trastocar ese orden y proponer uno distinto; la imagen que resiste destruye las equivalencias sígnicas y se abre a la posibilidad de las multivalencias, que desordenan el código y producen nuevos modos de significación, como sucede en el arte. Las imágenes creadas como prácticas de confrontación y espacios de denuncia nacen de una mirada crítica, un modo de ver el mundo que le permite a su autor moverse fuera del pensamiento dominante, haciendo evidente lo 
que el sistema de poder trata de ocultar, ya sea las fallas en su estructura, los personajes incómodos o las injusticias.

La denuncia hace visibles los aspectos que no están funcionando acorde con lo que trata de proyectar el sistema y lo vuelve vulnerable a la vez que lo abre a la posibilidad de transformación. García Canclini (2013) reflexiona en torno a la importancia del quehacer artístico como elemento transformador del orden social en tanto práctica externa a lo hegemónico, pues "la literatura y el arte dan resonancia a voces que proceden de lugares diversos de la sociedad y las escuchan de modos diferentes que otros, hacen con ellas algo distinto que los discursos políticos, sociológicos o religiosos" (p. 14).

Es preciso señalar que tales acciones poseen un alcance relativamente corto: surgen, desaparecen y vuelven a emerger; los artistas no pretenden lograr una revolución, entendida como avanzada a gran escala y de impacto extenso, sino desencadenar una serie de fenómenos pequeños que adquieren formas inesperadas e inciden en el modo de pensar del público. Así, hablar de la producción del libroarte en México como un espacio de resistencia implica llevar a cabo diversas prácticas de libertad: de ser, de hacer, de hallar rutas de sujeción a la norma, de proponer miradas desde la alteridad o la locura, de ejercer posturas críticas.

En este sentido, y considerando la resistencia como la manifestación de lo anómalo, la práctica de la libertad y de la construcción de discursos que retan los lineamientos de orden, el libroarte en México en el siglo XXI se proyecta como un espacio de expresión que permite construir relatos sobre ciertos acontecimientos en los que se ponen en crisis los discursos oficiales, así como recuperar y compartir la historia de aquellos sometidos $\mathrm{u}$ olvidados por los mecanismos de control. El libroarte funciona como un espacio en que los artistas exploran y presentan narrativas en torno a temas que los mecanismos de poder prefieren ocultar al público - nacional e internacional - creando una imagen distinta de la que proyectan los medios de comunicación y publicidad de fuentes oficiales.

Lo anterior conlleva un trabajo de creación de relatos en los que habitan todos aquellos que resultan prescindibles al sistema y cuyos modos de vida representan un riesgo para la estabilidad de sus discursos. El libroarte funciona entonces como depositario de relatos de la alteridad en los que se reformulan las versiones provenientes de la estructura de poder y permite la construcción de una historia otra de México. Al recuperar y conservar los modos de vida y órdenes simbólicos de la otredad, sus narraciones se vuelven parte de los mecanismos de defensa ante el que intenta controlar y normalizar a sus integrantes.

A través de las temáticas de la otredad se realizan ejercicios de crítica y denuncia social que proyectan al libroarte como un espacio en el que hablar acerca de los problemas que definen el presente en el país, desde los crímenes de Estado, hasta la discriminación, la situación económica, los ataques sufridos por diversos ciudadanos y grupos, sobre los cuales la postura oficial general es culpar a la víctima. Las piezas que alzan la voz en torno a estos temas adquieren un sentido político, dado que muestran una realidad distinta de la que proponen los sistemas de control y así exhiben sus fisuras, formando parte de las prácticas de resistencia. 


\section{Anna Maria Guasch: arte COMO ARCHIVO}

Guasch (2005) reflexiona en torno al creciente interés de los artistas por explorar en sus trabajos la relación con el archivo. Es decir, producir obras que funcionan como contenedores de información a la cual se puede acceder; a través de este proceso, mantienen presentes ciertos aconteceres en el imaginario colectivo y fungen a modo de documento histórico. Al igual que sucede con el archivo tradicional, estas obras son instrumentos que en su encuentro con el espectador le permiten consultar y conocer la historia de un lugar, un evento, una comunidad o una persona y detonar nuevas miradas en torno a ello.

Esta inclinación surge a partir de la década de los sesenta a la par de las corrientes de pensamiento que promulgan el fin de los grandes relatos y la necesidad de hallar nuevos modos de representación e interacción con el mundo. Estos ejercicios responden a una búsqueda de la preservación o construcción de una memoria colectiva narrada a través de los objetos artísticos. Siguiendo a Guasch, el interés por trabajar el archivo y la memoria responde a dos principios: "la fascinación por almacenar memoria (cosas salvadas a modo de recuerdos) y de salvar historia (cosas salvadas como información)" (2005, p. 158).

El arte como archivo deviene dos objetos: un testimonio que funciona como memoria y una ficción que se produce a partir de ella, pues estas obras utilizan objetos, documentos, datos y resignifican su información para construir un relato. Hablar de la memoria como un relato es relacionarla con lo ficticio, pues se trata de una interpretación de lo acontecido; se edifica en un proceso de traducción de aconteceres que toman forma a través de la subjetividad de su autor. El procedimiento implica una adaptación de su lenguaje primero (el acontecer) a un segundo código en el que se reordenan los elementos y los tiempos (la narración en sí).

Para producir tales ficciones, es necesaria una labor de almacenamiento, es decir, una colección, así como un montaje, que consiste en la selección y en el ordenamiento de elementos diversos. En conjunto, tales métodos formulan un pensamiento que deviene narración visual. En lo concerniente al libroarte, el archivo se traduce en una pieza en la que se organizan y conservan series de objetos o documentos ordenados a partir de patrones que permiten el intercambio de información entre sus componentes y como resultado producen la narrativa. El almacenamiento y el montaje como herramientas aplicadas al libroarte permiten seguir un hilo conductor, aunque la narración no se desarrolla de manera lineal, ofreciendo a sus lectores una especie de juego en el cual podrán crear su propia versión del relato a la vez que documenta y recupera, cumpliendo una función de conservación de la memoria.

La pieza crea colecciones de objetos para producir nuevas relaciones entre ellos, lo que deriva en órdenes de sentido distintos de los de su contexto original. Sus componentes se transforman en signos que permanecen como vestigios de un acontecimiento, de un modo de vida o de un proceso de interacción con el mundo en riesgo de desaparecer. Respecto del archivo, Didi-Huberman menciona que "lo propio del archivo es la laguna, su naturaleza agujereada" (s. f., p. 3), y en este sentido la aportación del 
libroarte no radica en mostrar toda la historia, sino solo algunas partes, desde las cuales el lector reconstruye el acontecimiento.

La obra funciona a manera de mapa a través de un tiempo que ya no es, haciendo presente su ausencia por medio del signo; así, el archivo, más que contenedor de verdades, es un objeto que posibilita la creación de narraciones y de enunciados. Bordons (2009) establece una relación entre el trabajo de Foucault y las obras de arte que funcionan como contenedores de información, señalando que los archivos posibles son aquellos que ofrecen la posibilidad de una aproximación compleja a la lectura de la historia, en sustitución al orden lineal que promulgan los grandes relatos. Bordons señala que se entiende "el término archivo como lo describió Michel Foucault como el sistema general de posibilidades de enunciados y en este caso de producciones visuales" (2009, pp. 88-89).

El libroarte como medio de documentación conserva historias de vida, costumbres, tradiciones de personajes y comunidades, lo cual lo transforma en un recipiente de la memoria social. Formula narrativas en las que puede habitar y permanecer lo que está en riesgo de olvido a través del rescate de aconteceres, eventos, objetos y documentos que de otro modo podrían desaparecer. En estas situaciones, el olvido es sinónimo de muerte - como el acto final, último - de una historia, de una persona o de un modo de vida.

En este caso, la memoria puede utilizarse como herramienta para la comprensión del presente, por lo cual funciona también como un elemento constructor de identidad, pues la lectura y re-lectura del pasado constituyen modos de afirmación y comprensión identitarios. A través de ello, estas piezas funcionan como archivos, objetos que permiten el almacenamiento de elementos, organizados acorde con un propósito específico, para su posterior consulta. El libroarte no expone certezas, sino que plantea posibilidades, ficciones que se construyen a partir de un acontecimiento; sus relatos difieren de los oficiales y en esa diferencia radica su resistencia.

\section{Casos específicos}

Para demostrar de qué manera el libroarte en México en el siglo XXI funciona como un espacio de resistencia, se han seleccionado dos casos específicos, acorde con las temáticas mencionadas; en ambos, las obras desembocan en relatos de la otredad y salvaguardan información, lo cual las coloca en la categoría de obras que fungen como archivos, aunque cada una con objetivos diferentes. En el primer caso, alzan la voz como espacios de denuncia y crítica social, señalando los aspectos en que falla la estructura de poder, mientras en el segundo abordan la preservación de la memoria colectiva; en este caso, la herencia prehispánica.

Esta necesidad de crear archivos en los que se almacena la memoria colectiva surge a causa del periodo de violencia, pobreza, corrupción e impunidad en México, cuya realidad se esconde tras la información ofrecida por las instituciones, que encubren los hechos al minimizar la gravedad del asunto, así como al culpabilizar a las víctimas y dejar en el olvido a los grupos vulnerables. Las piezas que se presentarán han sido exhibidas en distintas ferias alrededor del mundo e integradas a colecciones privadas, bibliotecas y colecciones especiales de universidades en diversos países. A través 
de sus relatos se da testimonio de una historia de México distinta de la ofrecida por versiones oficiales, en las que se conserva la memoria de ciertos personajes y eventos.

El primer caso aborda tres piezas que tratan el mismo tema, realizadas por distintos autores. Estas obras han adquirido relevancia internacional, se han presentado en diversas ferias de libroarte y pertenecen a colecciones especiales de universidades de prestigio, como la Universidad de Stanford. Se trata de reflexiones en torno a un mismo suceso desde la perspectiva particular de sus autores, por lo cual, aun cuando poseen un origen común, desembocan en objetos diferentes, tanto en cuestión de técnicas y materiales como en los procesos de construcción discursiva.

Tales obras reflexionan acerca de la desaparición de los 43 estudiantes normalistas de Ayotzinapa, ocurrida en septiembre de 2014, y crean un registro de sus consecuencias, pues, aunque las versiones oficiales varían, el sentimiento generalizado entre los mexicanos es que se trató de un crimen de Estado, ya sea porque fue ordenado desde puestos gubernamentales, ya sea porque los autores y ejecutores cuentan con su protección, lo que señala el grado de corrupción e impunidad en que se encuentra sumido el país. Sus relatos reflejan la reacción de la sociedad mexicana por medio de fotografías, textos e imágenes de creación propia.

Los sucesos de Ayotzinapa marcaron un antes y después en la historia reciente de México, unieron a la gente en el rechazo y contribuyeron a crear presión por parte de la comunidad internacional, exhibiendo las tremendas carencias que padece el país desde el punto de vista de la justicia. Tales acontecimientos derivan en la creación de los libroartes Ayotzinapa: desaparición politica de Pensaré Cartoneras en colaboración con Antonio Guerra, 43 de Lorena Velázquez y Desaparecen? de Pablo Ortiz Monasterio, editado por Nazraeli Press. A su condición de obra artística se suman la voz de denuncia que proyecta el suceso como un crimen de Estado y en ello se contrapone al discurso preparado por la estructura de poder, así como el carácter de archivo planteado por Guasch, dado que las fotografías y los documentos que conforman sus narrativas permanecen como testimonio de lo acontecido.

El segundo caso es el trabajo realizado por el Taller Leñateros en San Cristóbal de las Casas en Chiapas, que tiene cerca de cuarenta años funcionando cuyas obras son creadas por completo en sus instalaciones. El taller está conformado por artesanos y artistas locales que colaboran con poetas, escritores y traductores para realizar textos en maya que se traducen también al inglés y al español. El objetivo de este espacio es recuperar el idioma y aprovechar los materiales que ofrece la región para la creación de obras en las que se preservan y difunden la herencia y las tradiciones mayas. Gracias a este trabajo, la lengua maya ha vuelto a escribirse, después de casi cuatrocientos años de ausencia y su sistema de pensamiento se difunde alcanzando públicos de diversos entornos a escala internacional.

Las piezas que se presentan como parte del caso de estudio son Incantations (Past, 2005) y Mayan Hearts (Laughlin y Ojeda, 2002), que permiten a sus lectores conocer la manera en que los mayas entienden y reflexionan en torno a lo sobrenatural, los rituales, el amor y las emociones. Así, estas 
obras contribuyen a la construcción y conservación de la memoria colectiva, además de hacer presentes a ciertos grupos que la estructura de poder ha relegado, revalorizando su aporte a la formación identitaria.

\section{Ayotzinapa}

\section{"Ayotzinapa: desaparición política"}

Es una obra realizada en 2014 como fruto de una colaboración entre Pensaré Cartoneras y el artista plástico Antonio Guerra, quien contribuye con la imagen de portada; posee 56 páginas en las que se hallan tres tipos de elementos: un texto de reflexión en el que se aborda la situación política en México y los métodos de agresión del Estado dirigidos a las escuelas normalistas rurales, una serie de cartas de apoyo a los desaparecidos y sus familiares escritas por los estudiantes de la Facultad de Filosofía y Letras de la Universidad Nacional Autónoma de México (UNAM) y finalmente un conjunto de fotografías que registran las marchas de protesta posteriores a este acontecimiento.

Es una pieza fabricada con materiales de bajo costo y encuadernación en cartón reciclado, rasgos que recuperan las características de las editoriales cartoneras surgidas en la década de los setenta, que tenían un sentido democrático, pues se dedicaban a la creación de libros, panfletos y fanzines de contenido político y denuncia social, que pudieran alcanzar el mayor número de lectores generando consciencia entre su público, además de compartir información que ponía en duda los discursos de fuentes oficiales, en especial en aquellos países sometidos a gobiernos dictatoriales.

En Ayotzinapa: desaparición política, Pensaré Cartoneras recupera esta práctica tanto en la elaboración y materiales como en su contenido; como resultado se produce una pieza que puede circular dentro de la esfera artística, integrarse a las colecciones de diversas universidades y bibliotecas, ${ }^{2}$ y distribuirse a distintos públicos, a la cual se suma una versión que se puede consultar y descargar de modo gratuito en internet. La imagen de portada se repite en una página desplegable al interior del libro y muestra un mapa de México a partir de un conjunto de calaveras en tinta negra, siluetas trazadas en línea entre las cuales la correspondiente al estado de Guerrero posee una segunda tinta en rojo como una mancha que se extiende y escurre.

Al inicio, hay un pequeño escrito: "La tensión entre la desaparición y el número. La desaparición es un proceso infinito, el número afirma lo contrario". Mientras la desaparición es un concepto abstracto, el número es determinante y la hace tangible; enumerar y nombrar a los estudiantes los conserva en la memoria colectiva, en el relato histórico. $\mathrm{Al}$ interior de la pieza un primer segmento contiene la situación e historia de la escuela normal rural de Ayotzinapa, así como su significado en el país y cómo el derecho a la educación de los más pobres los vuelve víctimas de acoso, pues representa una amenaza a los intereses de muchos grupos en el poder. Se añade el testimonio de uno de los jóvenes presentes durante el ataque, por medio del cual se infiere que el encuentro estuvo planeado y el gobierno - estatal, por lo menos - involucrado, es decir, se trató de un crimen de Estado.

A lo largo de las páginas posteriores, se encuentra un conjunto de cartas escritas por

2 Por mencionar un ejemplo, una de ellas se encuentra en la Special Collection de la Universidad de Stanford, en California. 
estudiantes de la UNAM dirigidas a víctimas, sobrevivientes y familiares de los normalistas; expresan el apoyo a sus manifestaciones y movimientos de protesta en los que se pide justicia, reaparición de los jóvenes y castigo a los culpables, que sirven como ejemplo del apoyo que les ha expresado la sociedad mexicana y el repudio que se siente ante las acciones gubernamentales. Las fotografías presentan un registro de las marchas y ofrendas en honor de los estudiantes desaparecidos, carteles en los que se lee "Nos faltan 43" y "Ayotzinapa somos todos", frases que desde 2014 han sido constantemente repetidas así como las imágenes

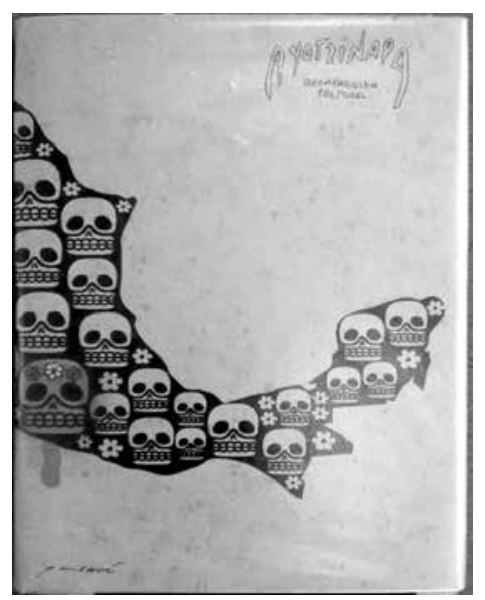

Figura 1A.

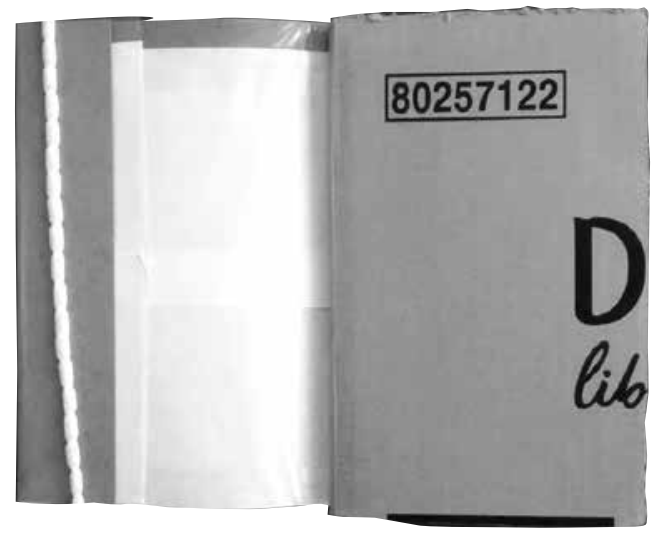

Figura 1B. de estos jóvenes con sus respectivos nombres. En conjunto, las fotografías y cartas de apoyo construyen una visión panorámica del sentir en el país.

La narrativa creada a partir de estos elementos expone al territorio nacional como un lugar donde la muerte se desborda, una muerte proveniente de la violencia sistemática concebida y protegida por el aparato de Estado, que se manifiesta en la desaparición forzada de un grupo de jóvenes estudiantes. Así, la pieza conserva su recuerdo en la memoria social y propone una lectura distinta de los hechos de la de comunicados oficiales; se trata de una reflexión sobre la paradoja de la desaparición como un acto que exhibe las fallas de un sistema de poder. Ayotzinapa: desaparición política es el registro de un ataque a estudiantes y la movilización nacional que surge en consecuencia. Es un ejercicio de memoria y denuncia social que intenta salvaguardar un episodio en la historia nacional frente a un sistema que intentaba esconder o restar importancia a lo sucedido (figura $1 A, 1 B$ y $1 C$ ).

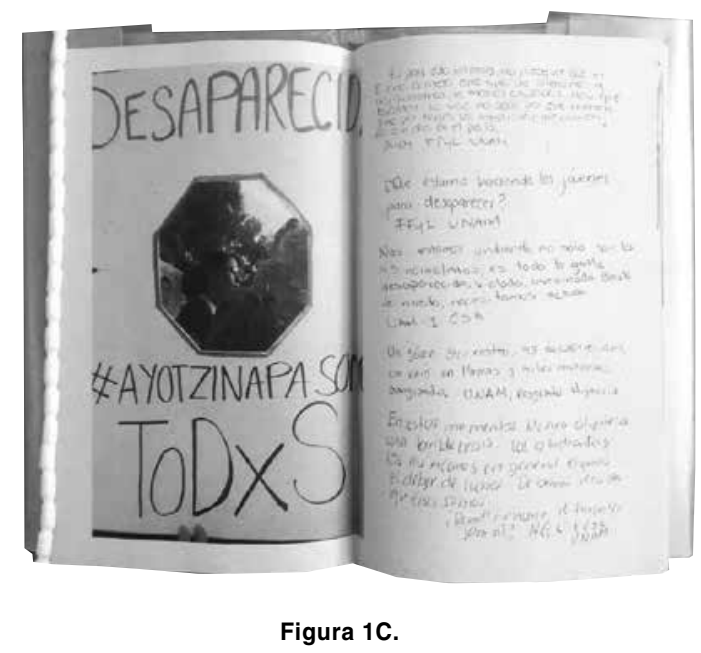

Fuente: elaboración propia 
“43"

La segunda obra se titula 43 y es autoría de la artista visual Lorena Velázquez. Fue realizada en 2015 con una edición de 43 ejemplares firmados y numerados, cada uno de 43 páginas; sus medidas son $21,5 \times 21,5 \times 5$ $\mathrm{cm}$, que da $43 \mathrm{~cm}$ como medida total cuando se abre y despliega. Es una obra cuidadosamente elaborada con materiales de primera calidad y en edición limitada, un libroarte concebido para mostrarse en ferias y galerías, dirigido a un público selecto y con altas posibilidades adquisitivas.

El título ya denota una serie de implicaciones de carácter político y social presentes en el imaginario colectivo, signo de la violencia que el aparato de Estado y su brazo armado ejercen sobre la ciudadanía, que serán expresadas de diferentes maneras a lo largo de sus páginas. Se trata de una pieza cuyos elementos formales, conceptuales y discursivos giran en torno a este número en cada secuencia de la narrativa. 43 retoma imágenes de marchas y movimientos de protesta, los nombres de los normalistas, sus huellas digitales, la reproducción de sus retratos, a los cuales integra elementos de su propia creación para reconstruir la identidad de los jóvenes.

La paleta de color se compone de negro en las páginas, empastados y contenedor; blanco y rojo en las tintas de impresión de serigrafía siguiendo siempre el mismo orden: el fondo negro del papel, la impresión de textos y figuras en blanco y la intervención en manchas rojas. Se abre al separar la portada, unida por una costura roja como herida suturada a manera de la realizada en un cuerpo al finalizar una necropsia; lo burdo de las costuras y el grosor del hilo refieren al caos y la violencia en México, exponiendo una de las mayores fisuras o heridas en su estructura.

La narrativa inicia con un texto de Anónimus publicado en las redes sociales:

No soy hijo de ningún concepto nacional, aunque retiemble en su centro la tierra, porque no puedo estar a favor de tanto bélico acento. La muerte de un hombre es una tragedia, la de millones es una estadística... Cuando me dices que los muertos caben en una cifra o en un cofre siento que crees que la paz sólo se produce con el miedo y por eso acribillas las palabras de miles de personas; por eso me dices que la violencia es el precio de la paz, que la escalada de violencia es en nombre de la felicidad, de la unidad y de la prosperidad nacional.

Les prestamos nuestros dedos y cada uno de nuestros cabellos, cuéntennos: somos mayoría los vivos, los no acarreados, los no abanderados, los que no aceptamos el discurso oficial, los abanderados del no, la escolta del no.

Al salir a la calle por primera vez nos convertimos en protagonistas. No somos más la multitud anónima, porque ahora somos una sola voz que aprende las consignas en tu contra. Somos gente con traje de oficinista, gente que carga a los niños, gente con bolsas del mandado, gente ... gente que ya no tiene miedo, porque estamos entre gente. Yo ya no le tengo miedo a la gente y mucha gente ya no le tiene miedo a la gente, y ya no tenemos miedo de estar vivos, a pesar de que en México estar vivos es un acto subversivo, es una conspiración a la vida ...

Anónimus. 
Señala un claro repudio de la sociedad en general ante las acciones llevadas a cabo por el Estado. Primero, al participar en la desaparición de los normalistas $\mathrm{y}$, posteriormente, en la respuesta que ofreció cuando se exigió una solución y justicia para ellos y sus familiares. Al texto le siguen imágenes de marchas y elementos elegidos por la autora para fungir como signos que representan a los jóvenes: la numeración del 1 al 43, sus nombres y huellas digitales, impresos en color blanco y siempre acompañados por manchas rojas. Esto crea un alto contraste, un encuentro entre luz y oscuridad en tanto blanco y negro son extremos: el blanco es la suma de todos los colores mientras el negro es su falta, la desaparición de la luz.

Las figuras en blanco indican algo que no está ahí, hacen visibles a los desaparecidos; se vuelven signo de vida en tanto hacen presente su ausencia, lo cual se complementa

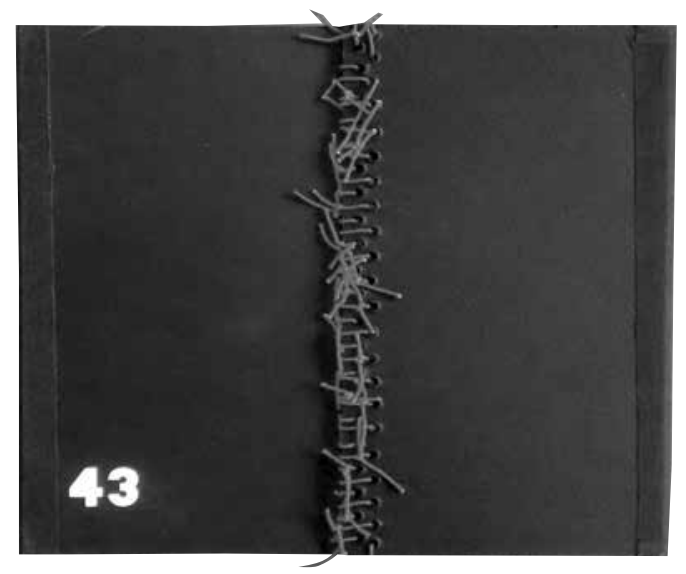

Figura 2A. en relación con el color negro, que habla del vacío y de la muerte. El blanco en todas las formas que adquiere el 43 trae de vuelta la historia de los normalistas, los rescata del vacío del olvido; el rojo es la sangre que ha marcado el rastro de los jóvenes, atraviesa las páginas y es punto de unión entre los extremos, conectando la presencia del blanco a la ausencia implícita en el negro.

La obra exhibe la violencia del aparato de Estado y conserva la memoria de los normalistas; es una denuncia al sistema que pretende sepultarlos en el vacío, por tal razón los representa en color blanco, que los trae de vuelta. Es una acusación a los organismos y las instituciones que han fallado en proveer resultados satisfactorios; con ello, se realiza también un ejercicio de recuperación de un acontecimiento y lo preserva en la memoria colectiva (figuras $2 A, 2 B$ y $2 C$ ).

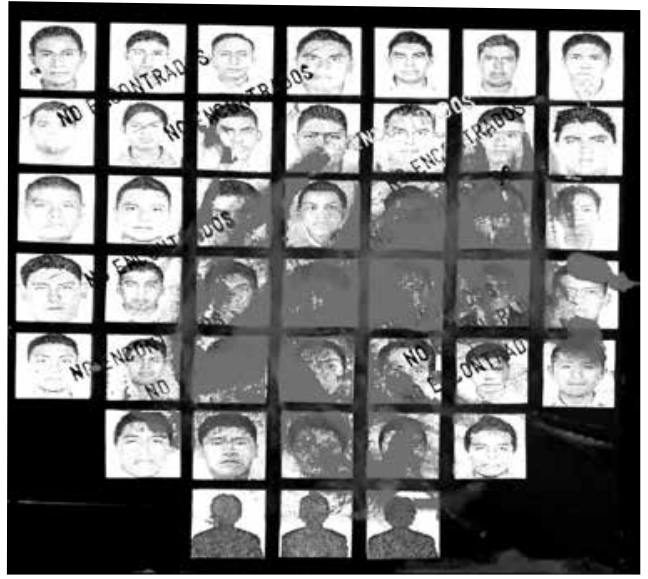

Figura 2B. 


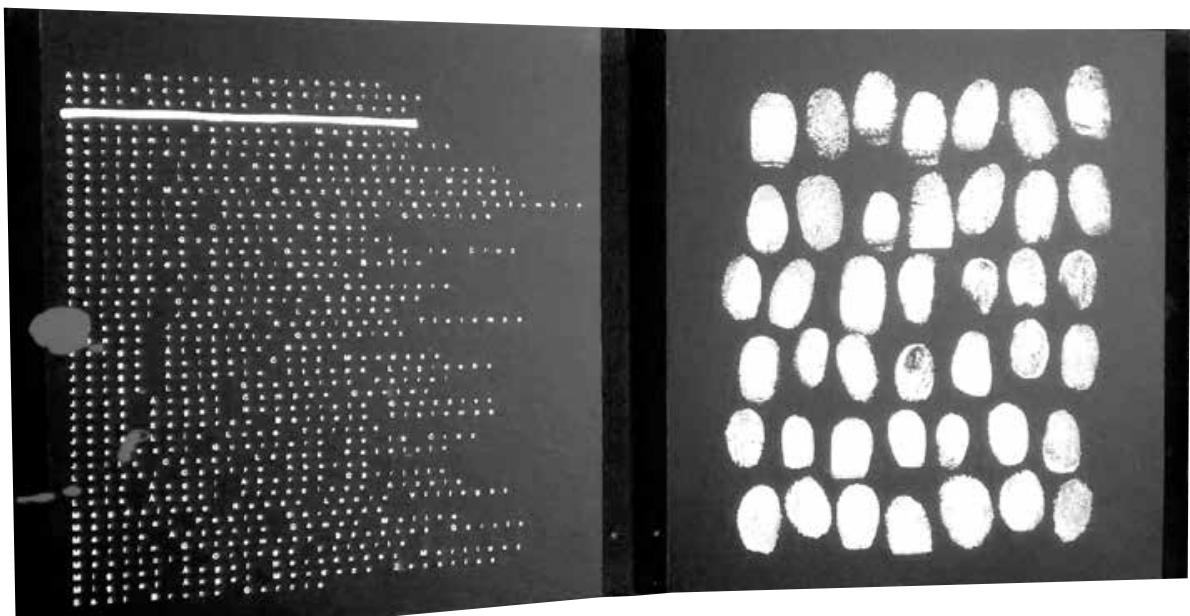

Figura 2C.

Fuente: elaboración propia

\section{“Desaparecen?"}

Desaparecen? se conforma a partir de una colección de textos de prensa y una serie de imágenes del fotógrafo mexicano Pablo Ortiz Monasterio. Se realizaron dos tirajes distintos: una edición de bajo costo accesible al grueso del público, que se distribuyó en distintos puntos del país, y una edición limitada para la cual se utilizaron materiales de mayor calidad; esta última consta de 43 copias firmadas y numeradas, y una extensión de 111 cm (43 in), mientras la versión económica es de menor tamaño.

Los materiales de la edición económica hacen referencia a los limitados recursos de los estudiantes en las escuelas normales rurales; así, la pieza mantiene un cierto sentido de humildad que retrata el entorno del que provienen los jóvenes desaparecidos. La impresión se hizo en papel cartón con encuadernado a partir de grapas de metal, de manera que los bajos costos de producción la vuelven accesible a lectores y compradores en México y le permiten un proceso de circulación que trasciende al mundo artístico. En contraste, la edición de lujo se realizó en papel de mayor calidad y se agregó un contenedor de obra; las ganancias de este tiraje limitado se destinaron a los gastos de producción y distribución de su versión económica.

El método de elaboración se basa en el foto-collage, que en este caso es análogo al proceso de montaje; esto implica que su autor utiliza imágenes y textos diversos, los coloca en un determinado orden y construye una narrativa a partir de las relaciones que entablan entre ellos. La portada es una fotografía de un ojo en blanco y negro en cuyo iris se ve una proyección difusa del número 43; sobre ella la palabra "Desaparecen?" con un signo de interrogación al final, perfectamente enfocada. El 43 se encuentra presente de distintas maneras en varios escenarios, ya sea como un texto agregado a las imágenes, ya sea como una sombra que se proyecta sobre el pavimento o se descubre en el cielo, como un recordatorio constante de 
lo ocurrido. Algunos fragmentos del poema Ayotzinapa, autoría de David Huerta, dan inicio a la narrativa; en páginas posteriores, se encontrará el poema en extenso.

Quien esto lea debe saber
que fue lanzado al mar de humo
de las ciudades
como una señal del espíritu roto
quien esto lea debe saber también
que a pesar de todo
los muertos no se han ido
ni los han hecho desaparecer
de todos los que son
y de todos los que se han ido

La pieza contiene un listado en gris sobre negro con los nombres de los normalistas desaparecidos y una serie de recortes de prensa extraídos del New York Review of Books y autoría de Alma Guillermoprieto, así como la transcripción de una entrevista realizada por Carmen Aristegui. El texto, redactado en inglés, presenta una crónica de las condiciones de la zona que eventualmente llevarán a la desaparición de los estudiantes y expone que no se trata de un incidente aislado, sino de una estrategia recurrente del Estado mexicano.

Estos escritos se complementan con fotografías de los estudiantes, acompañadas por la leyenda "Vivo se lo llevaron. Con vida lo queremos". Junto a ellas, una silueta más en negro que alude a su ausencia y señala - como menciona una de las frases repetidas en las marchas de protesta - "Ayotzinapa somos todos". A partir de este punto, la narrativa se enfoca en los componentes visuales intervenidos con números, signos de puntuación y palabras; a lo largo de toda la obra aparece la numeración como una sombra que se proyecta sobre el paisaje, y en el cielo, un recordatorio constante de la ausencia de los normalistas y de todos los desaparecidos en el país.

Se incluye una serie de figuras que remiten a la muerte desde la iconografía religiosa prehispánica y cristiana intervenidas con texto y números, en que se pregunta dónde están los normalistas, así como siguiendo la numeración que conduce al 43 , con la intención de mantener presente el recuerdo y el interrogante. El número se vuelve signo de la desaparición, de la ausencia, de la lucha frente al olvido que pretende lograr el sistema. El número/signo cubre tierra y cielo mexicanos, se manifiesta en todos los entornos: urbanos, rurales, de construcción prehispánica como la huella que dejan los estudiantes, haciendo presente su ausencia en lo cotidiano y en el imaginario colectivo. En la última página, la frase "A la memoria de los muchachos que se llevaron".

Esta obra conserva vivo el recuerdo de los normalistas y su huella en la historia de México; su desaparición deja un rastro que ha transformado el paisaje y a todos aquellos que lo habitan o recorren. La pieza funciona como un archivo en el que se guarda y conserva su memoria, a la vez que un instrumento de denuncia a la violencia del Estado mexicano, un relato al cual pueden acceder lectores de diversos lugares y conocer la situación que atraviesa el país (figuras $3 A, 3 B$ y $3 C$ ).

\section{Taller Leñateros}

Taller Leñateros es un taller ubicado en San Cristóbal de las Casas, en Chiapas. Toma su nombre de los indígenas de la zona que recogen hierbas, flores, musgo, madera para hacer leña y vuelven a sus comunidades y a San Cristóbal para venderlos; 


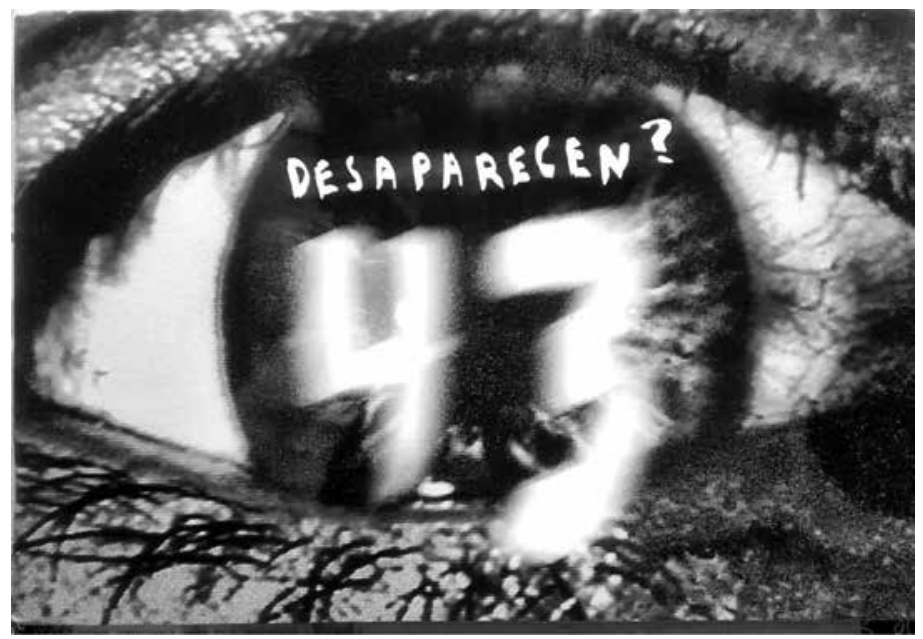

Figura 3A.

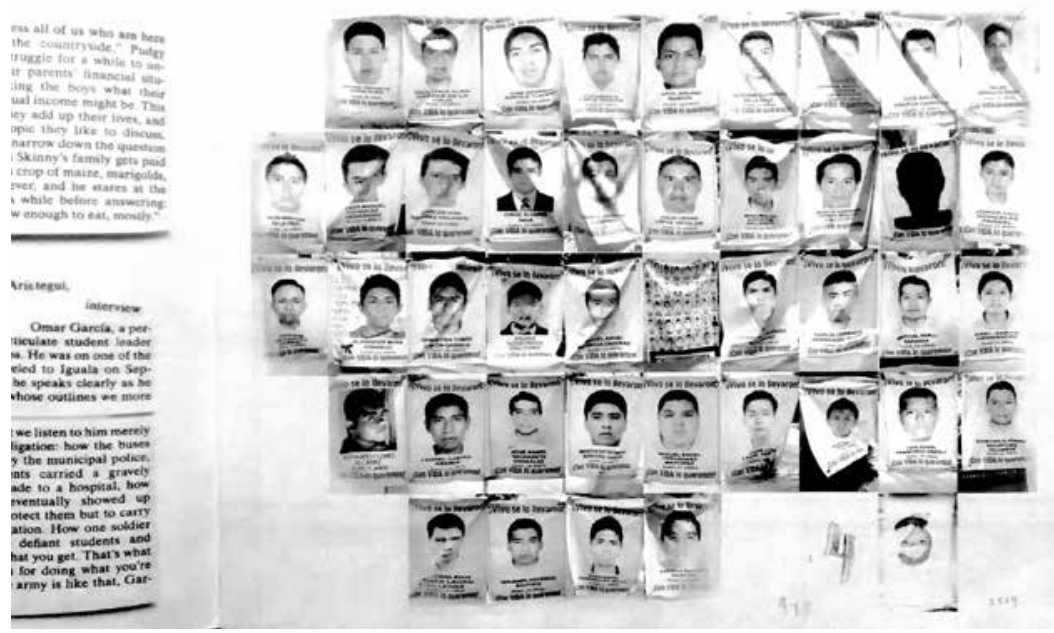

Figura 3B.

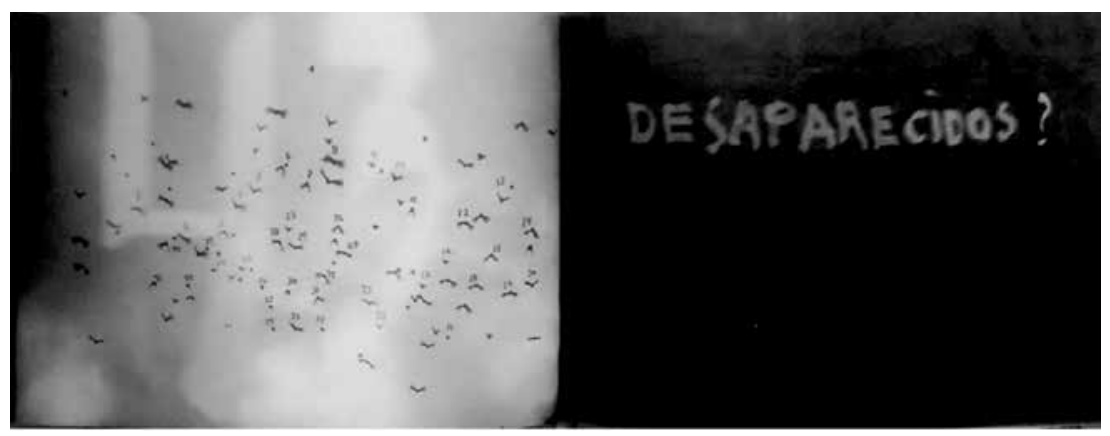

Figura 3C.

Fuente: elaboración propia 
su característica radica en que no talan los árboles, solo toman la madera que ya está en el suelo, de modo que no dañan la vegetación del lugar. El taller fue fundado en 1975 por la poetisa norteamericana Ambar Past, quien llegó a vivir entre ellos, aprendió el idioma y en sus costumbres identificó el sentido poético presente en las actividades cotidianas, como los cantos, rezos y conjuros tradicionales para el amor y la salud.

Interesada en la recuperación de la escritura en lengua maya, Past comenzó a experimentar con la fabricación de papel a partir de materiales locales que les permitieran plasmar estos cantos y rezos para su difusión y conservación; así, se fundó primero el Taller de Sueños, que posteriormente se transformó en Taller Leñateros. Se trata de la primera editorial en lengua maya, dedicada a la elaboración y venta de libroarte que contiene textos en este idioma, así como cantos, recetas, leyendas y juegos de magia tradicional. Los textos se acompañan por una traducción, ya sea al inglés, ya sea al español, de manera que sus lectores fuera de la comunidad puedan comprender su significado y apreciar su legado.

El taller fabrica y vende diversos objetos además de los libros: papel, ropa, artesanía, aunque su objetivo principal consiste en la recuperación, preservación y difusión de la herencia maya, su lenguaje y su manera de aprehender el mundo. Su singularidad radica en que está dedicado en exclusiva a la producción de libros que contienen relatos, usos y costumbres que se han ido perdiendo ante los embates de la globalización; de esta manera, se conservan sus tradiciones y la escritura vuelve a estar presente en la cultura maya, después de casi cuatro siglos de ausencia. Es manejado y trabajado por indígenas locales quienes fabrican los materiales y objetos, desde el papel con fibras vegetales de la región, tintas naturales, empastados, imágenes, procesos de estampa y encuadernación.

Las obras son hechas por completo a mano por los artistas y artesanos del taller y se fabrican dos tipos de ediciones: las de lujo, que son expuestas para su venta en ferias de libroarte, colecciones universitarias, museos, y copias de menor costo y tamaño para incrementar las posibilidades de venta entre el público en general. A lo largo de su historia, el trabajo de este taller ha recibido premios y reconocimientos tanto en México como en el extranjero, y sus piezas pertenecen a colecciones de importantes museos y universidades. A pesar del olvido y de la pobreza en que se encuentran las comunidades indígenas en el país, gracias al esfuerzo de Taller Leñateros, el legado de las costumbres y tradiciones mayas se difunde y conserva como parte de la herencia cultural y la memoria colectiva de México.

\section{"Mayan hearts"}

Este libroarte se realizó en 2002 con una edición de 500 ejemplares. Consta de 116 páginas y mide $23 \times 28 \times 2,5 \mathrm{~cm}$. Se inspira en un diccionario tzotzil-maya-español que data del siglo XVI, que contiene una traducción de las distintas maneras en que los habitantes de Zinazantán en Chiapas expresan emociones y sentimientos a partir de la figura del corazón. El diccionario original es trabajo de un fraile español desconocido, quien llegó a la comunidad de Santo Domingo Zinacantán alrededor de 1599 para la conversión de los indígenas al cristianismo. En su encuentro con los habitantes, 
descubrió que poseían un lenguaje con múltiples expresiones relacionadas con el corazón, figura central a partir de la cual se desprenden diferentes formas de referir a emociones y situaciones.

Acorde con esta cosmogonía, en el corazón se origina el sentir, pero también los asuntos relacionados con el pensamiento y el buen juicio, es decir, tanto la mente como el sentimiento provienen de un mismo sitio; solo después de la conquista se separaron el corazón y la mente colocados uno en el pecho y otro en la cabeza. El fraile halló más de ochenta metáforas a partir de la figura del corazón, las cuales tradujo en un diccionario que con el tiempo se integró a la colección de libros de la Universidad de Princeton, donde estudió Robert M. Laughlin, curador del Departamento de Antropología Mexicana en el Museo Smithsonian en Washington, D. C., quien lo toma como punto de partida para la creación de Mayan hearts.

En esta obra, se eligieron veinte de las metáforas del corazón, traducidas al español e inglés, así como algunas guías gramaticales y de pronunciación. De esta manera, se lleva a cabo un trabajo de difusión de la lengua aunado al proceso de conservación, pues, al plasmarse sobre el papel y transformarse en un libro - un objeto físico - se integra a la memoria humana tangible. Así, por ejemplo, la expresión $\mathrm{Xk}^{\prime} \mathrm{uxub}$ Kolonton, que se traduce literalmente como "Mi corazón duele" significa "estar enamorado" y se representa con una pareja abrazada, Ch'ilom kolonton se traduce como "Mi corazón es un guerrero" y significa "ser cruel" representada en una página desplegable con un puño en alto y un corazón en la muñeca, "Xmuk'ub kolonton" se traduce como "Mi corazón crece" y significa "ser valiente" acompañada de la imagen de un sol rojo que lo abarca todo como una llama que se extiende.

El texto de la obra es autoría de Laughlin, al cual se suma un conjunto de imágenes hechas en xilografía e impresas a dos tintas realizadas por el artista uruguayo Naúl Ojeda, quien lleva a cabo un nuevo proceso de traducción, esta vez de la escritura a la visualidad. La paleta de color se compone del blanco crudo que proporciona el papel, tinta roja y negra. La portada es negra con un bajorrelieve en forma de corazón rojo. Las xilografías presentan imágenes del corazón, figuras humanas, cuerpos celestes.

En conjunto, los elementos de este libroarte construyen una narrativa que guía al lector a través de la cosmogonía maya y tzotzil y le permite comprender las variaciones derivadas del sentir de esta sociedad prehispánica, que vuelve a estar presente en la escritura mexicana: viajar y conectarse con nuevos públicos (figuras $4 A, 4 B, 4 C$ y $4 D$ ).

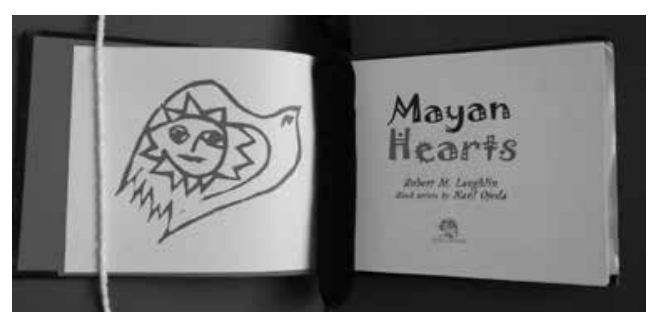

Figura 4A.

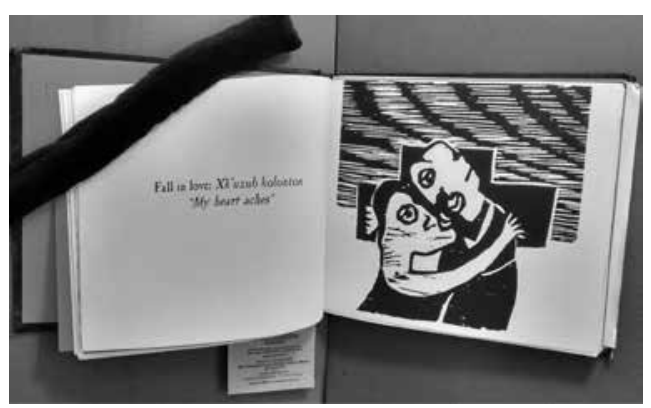

Figura 4B. 


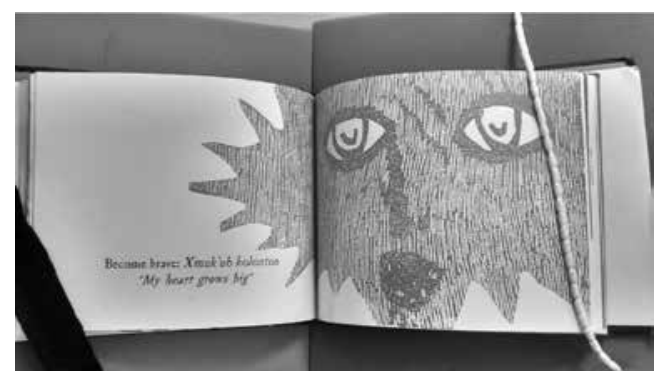

Figura $4 C$.

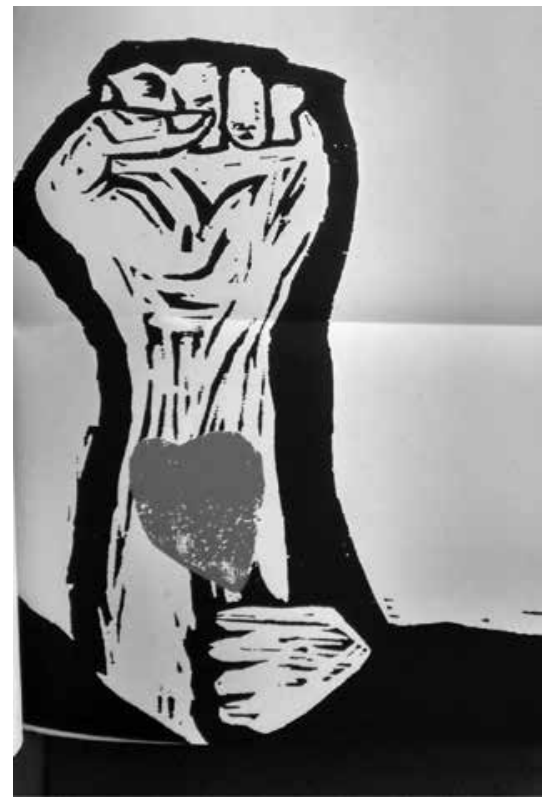

Figura $4 D$.

Fuente: elaboración propia

\section{"Incantations. Conjuros y ebriedades: cantos de mujeres mayas"}

Incantations es un libroarte realizado en 2005. Forma parte de diversas bibliotecas fuera del país, entre ellas, la de la Universidad de Stanford y la colección permanente del Museo Nacional de Mujeres en el Arte de Washington, D. C. Es una antología que contiene una serie de rezos y cantos mágicos, así como pinturas rituales de las mujeres tzotzil que habitan en los Altos de Chiapas. El texto fue impreso en tzotzil, inglés y español.

En este libroarte, pueden hallarse distintos hechizos de amor, conocidos y practicados por los habitantes de la región y transmitidos durante siglos de generación en generación por medio de la tradición oral, de abuelas a nietas y de madres a hijas. Aquí se encuentran fragmentos de las canciones y de los ritos para atraer el amor, hacer curaciones, llevar a cabo encantamientos que forman parte de la tradición prehispánica sobreviviente a la conquista europea, el pensamiento occidental y la globalización. Forman parte de la memoria de estos pueblos y se mantienen en uso hasta la actualidad como parte del imaginario maya.

La narrativa se construye en tres segmentos: comienza con un texto de introducción a la cosmogonía tzotzil y el nacimiento de sus cantos y rezos; posteriormente, se encuentra la colección de leyendas y encantamientos, combinados con imágenes de las mujeres que los llevan a cabo. La primera parte es un escrito que narra cómo surgieron estos cantos, sabiduría que les fue otorgada en sueños a las mujeres habitantes de la región de los Altos de Chiapas. Acorde con el texto, las canciones provienen de los primeros padres-madres, que son los guardianes del Gran Libro en el que todas las palabras han sido escritas.

La historia narra de qué manera la vidente analfabeta de Santiago El Pinar, llamada Pasakwala Komes, aprendió estos conjuros al soñar con el Gran Libro, así como Loxa Jimenés Lopes de la comunidad de Epal Ch'en en Chamula cuenta acerca de Anjel, la hija del Señor de las Cuevas, quien en sueños le susurró los cantos y después le mostró el Libro con todas las palabras mágicas. 
Puede decirse que Incantations es, en cierto modo, un libro de las sombras de la cultura maya. Los libros de las sombras son manuscritos medievales europeos que contenían hechizos y conjuros del paganismo precristiano, utilizados por las brujas para consulta, creación de nuevos encantamientos y conservación de los existentes; tales manuscritos son a la vez origen de los tratados de alquimia y posteriormente de ciencia, y en este sentido se localiza un paralelismo entre ellos y los cantos presentados en Incantations, pues, aunque se originan en las prácticas mágico-religiosas del prehispánico, también contienen recetas y guías para restaurar la salud espiritual y física. Desde esta perspectiva, la pieza no se limita a la narración de historias fantásticas, sino permite conocer, apreciar y conservar tanto los órdenes simbólicos de una sociedad como sus saberes en cuestión de medicina, que a través de su lectura se protegen del olvido.

La portada de la obra es una máscara de papel hecho a mano en alto y bajorrelieve, y se encuentra tanto en la edición de bajo costo como en la realizada con materiales más caros. La edición de lujo es de mayor tamaño e incluye una caja de cartón que sirve como su contenedor, mientras la edición económica es pequeña y carece de la caja de presentación. La paleta de color se compone del blanco crudo del papel, beige como fondo en algunas imágenes y negro en trazos y textos. A lo largo de toda la pieza las imágenes muestran diversos tipos de figuras con líneas que remiten a dibujos infantiles, lo cual les otorga un carácter de inocencia; representan formas femeninas que hacen su preparación de hechizos, así como plantas y animales sagrados en la cultura maya.

En conjunto, parecería que se trata de algún tipo de recetario de medicina herbolaria tradicional mexicana, a excepción de los cantos para atraer el amor de un hombre. Al leer estos, se entiende claramente el sentido mágico y ritual de los rezos, la conexión que sienten los tzotzil y mayas con la naturaleza, y la presencia de los espíritus de un pasado que ni el tiempo, ni la pobreza en que viven los indígenas en México, ni la globalización han podido desaparecer. De este modo, el trabajo de Incantations contribuye a la supervivencia de una cultura que habita el territorio nacional desde mucho antes que llegaran el pensamiento y la estructura social provenientes de Europa (figura 5).

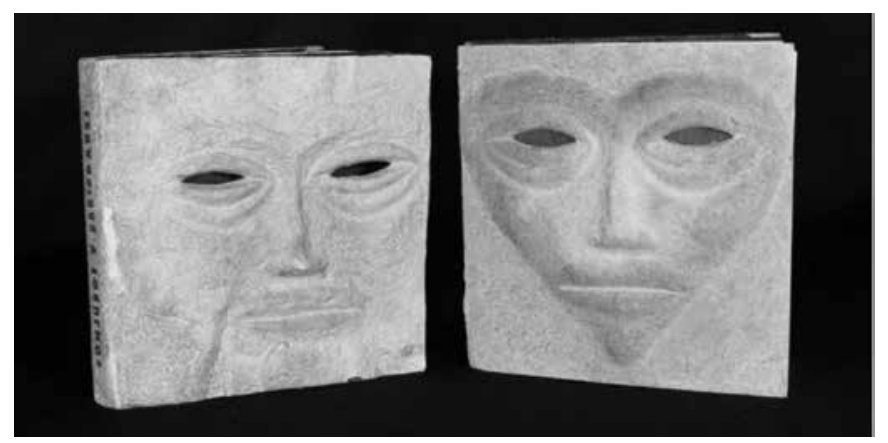

Figura 5.

Fuente: elaboración propia 


\section{Conclusiones}

El libroarte es una vertiente plástica que aparece en la segunda mitad del siglo $X X$ y propone nuevos modos de aproximación al objeto-libro; comprende toda obra de arte concebida o realizada a partir del libro común, y se apropia de sus características físicas para llevarlas al contexto de la visualidad. Sus autores exploran el juego entre texto e imagen construyendo nuevas clases de narrativas y creando una relación de cercanía con sus lectores/espectadores, pues, a diferencia de la obra de arte tradicional, se les invita a tocar y manipularlas.

El libroarte llega a México en la década de los setenta gracias al trabajo de Ulises Carrión y Felipe Ehrenberg, quienes en Europa entraron en contacto con corrientes artísticas y filosóficas que experimentaban con el lenguaje y con los objetos cotidianos, reflexionaban en torno al fin de los grandes relatos y la necesidad de crear nuevos modos de relación con el arte. Durante los siguientes veinte años, surgen y se desarrollan en el país diversos proyectos y colectivos interesados en la creación de estas piezas, aunque es hasta el siglo XXI cuando el libroarte ha tenido un verdadero crecimiento en el país, un aumento en su producción, así como nuevos trabajos de investigación y foros de discusión.

Las temáticas relacionadas con la denuncia, la crítica social y la conservación de la memoria colectiva son recurrentes en el trabajo de los artistas y de este modo el libroarte se proyecta como un espacio en el que reconstruir los discursos oficiales a partir del rescate y de la conservación de las historias de vida pertenecientes a esos otros que le resultan incómodos al sistema. Así, se transforma en un espacio de relatos de la otredad en los que tienen cabida todos aquellos que los mecanismos de poder tratan de ocultar, resultando en dispositivos de resistencia social.

Lo anterior es posible en tanto el libroarte trabaja el rescate y almacenamiento de la memoria colectiva y actúa como medio de denuncia y crítica social. En el primer caso, la obra es una huella que permanece; en el segundo, permite exponer las fisuras en la estructura de poder. De esta manera, se ponen en crisis los discursos que pretenden homogeneizar el pensamiento y los modos de vida. Partiendo del entendido del poder como un mecanismo que pretende encubrir la realidad bajo un velo de signos hegemónicos, entre sus fisuras se cuelan las miradas otras y muestran un relato distinto.

La producción de imágenes tiene connotación política e incidencia en el campo de lo social, por esta razón puede ser utilizada por los mecanismos de poder a manera de instrumento de regulación de pensamiento, pero también a modo de resistencia como un objeto detonante de subjetividades y capaz de provocar una mirada crítica que cuestiona los lineamientos de conducta impuestos por el sistema.

El libroarte se transforma en un dispositivo de resistencia en tanto exhibe los problemas de carácter social, político y económico que intentan ocultarse del público, un espacio de denuncia y documento histórico. Contribuye a crear un relato nacional alterno a través de narraciones desde la otredad, que muestran puntos de vista distintos del discurso oficial dado, ofrece una multiplicidad de miradas en contraste con el mecanismo que unifica el pensamiento y los modos 
de vida. Sus narraciones permanecen como la huella de lo sucedido; así, las piezas funcionan como contenedores de una memoria que se trata de borrar o manipular para mantener la estructura de dominación.

Con ello, estas piezas se proyectan como archivos: obras que permiten guardar y consultar información, espacios en los que se recuperan y conservan relatos que corren el riesgo de desaparición ante los discursos del sistema de poder, ya que, al detonar nuevos modos de mirar la historia, producen subjetividades que resisten a la individualización impuesta por el sistema de orden.

\section{REFERENCIAS}

Baudrillard, J. (1969). El sistema de los objetos. Ciudad de México, México: Siglo XXI.

Bordons Gangas, T. (2009). Archivos posibles. Estudios visuales: Ensayo, teoría y crítica de la cultura visual y el arte contemporáneo, 6, 81-91. Recuperado de https://dialnet.unirioja.es/servlet/ articulo? codigo $=3018370$

Britos, M. (2003). Michel Foucault: del orden del discurso a una pragmática de lo múltiple. Tópicos, 11, 63-82. Recuperado de http://www.uacm.kirj.redalyc. redalyc.org/articulo.oa?id=28801104

Crespo, B. (1999). El libroarte: concepto y proceso de una creación contemporánea (Tesis doctoral, Universitat de Barcelona, Barcelona, España).

Crespo, B. (2014). El libro de artista de ayer a hoy. Seis ancestros del libro de artista contemporáneo: primeras aproximaciones y precedentes inmediatos. Arte, Individuo y Sociedad, 26(2), 215-232.
Recuperado de http://revistas.ucm.es/ index.php/ARIS/article/view/41347

Didi-Huberman, G. (s. f.). Cuando las imágenes tocan lo real. Recuperado de http:// www.macba.cat/uploads/20080408/ Georges_Didi_Huberman_Cuando_ las_imagenes_tocan_lo_real.pdf

Didi-Huberman, G. (2008). Cuando las imágenes toman posición. Madrid, España: Antonio Machado Libros.

Foucault, M. (1984). Vigilar y castigar: nacimiento de la prisión. Ciudad de México, México: Siglo XXI.

Foucault, M. (1991a). El sujeto y el poder. Bogotá, Colombia: Carpe Diem.

Foucault, M. (1991b). Hacer vivir y dejar morir: la guerra como racismo. Archipiélago: Cuadernos de Crítica de la Cultura, 7, 75-93.

Foucault, M. (2001). Los anormales: Curso en el Collège de France (1974-1975). Ciudad de México, México: Fondo de Cultura Económica.

García Canclini, N. (2013). ¿De qué hablamos cuando hablamos de resistencia? RevistArquis, 2(1). Recuperado de http://repositorio.ucr.ac.cr/bitstream/ handle/10669/13666/8618-12268-1-PB. pdf?sequence $=1$ \&isAllowed $=y$

Giraldo Díaz, R. (2006). Poder y resistencia en Michel Foucault. Tabula Rasa, 4, 103-122. Recuperado de http://www. redalyc.org/articulo.oa?id=39600406

Giraldo Díaz, R. (2008). La resistencia y la estética de la existencia en Michel Foucault. Entramado, 4(2), 90-100. Recuperado de http://www.redalyc.org/articulo.oa?id=265420459008

Guasch, A. M. (2005). Los lugares de la memoria: el arte de archivar y recordar. Materia, 5, 157-183. Recuperado de 
https://www.raco.cat/index.php/Mate ria/article/viewFile/83233/1124

Guerra, A. (2014) Ayotzinapa: desaparición política. Ciudad de México, México: Pensaré Cartoneras.

Gunst, E. (2018, enero 16). Ambar Past, Nocturno para leñateros [Entrada blog]. Recuperado de https://emmagunst. blogspot.com/2018/01/ambar-past-nocturno-para-lenateros.html

Ortiz Monasterio, P. (2015). Desaparecen? Nazraeli Press. Recuperado de http:// www.nazraeli.com/complete-catalogue/pablo-ortiz-monasterio-desaparecen-special-edition

Laughlin, R. M. y Ojeda, N. (2002). Mayan hearts. Ciudad de México, México: Taller Leñateros.
Past, A. (2005). Incantations. Conjuros y ebriedades: cantos de mujeres mayas. Ciudad de México, México: Taller Leñateros.

Raffin, M. (2008). El pensamiento de Gilles Deleuze y Michel Foucault en cuestión: las ideas en torno del poder, el sujeto y la verdad. Lecciones y ensayos, 85, 17-44. Recuperado de http://www. derecho.uba.ar/publicaciones/lye/revistas/85/02-leccion-marcelo-raffin.pdf

Schraenen, G. (2015). Querido lector, no lea. Madrid: Museo Reina Sofía.

Velázquez, L. (2015). 43. Ciudad de México. Recuperado de http://www.tallerlenateros.com/libros.php?ira=libros 